\title{
The Effect Of Temperature To 3D Change Rock Structure On Caprock Of The Area Of Geothermal Potential In Kadidia - Sigi, Central Sulawesi
}

\author{
I Assidiq ${ }^{1}$, A Nadhira ${ }^{2}$, S Feranie $^{3}$, and F D E Latief ${ }^{4}$ \\ \{assidiq.iqba191@gmail.com ${ }^{1}$ \} \\ Digital Rock Physics and Soil Mechanical Laboratory, Physics Program, Department of Physics \\ Education, Faculty of Mathematics and Natural Sciences Education, Universitas Pendidikan Indonesia, \\ Bandung, Indonesia ${ }^{1,2,3}$

\begin{abstract}
Kadidia-Sigi, Central Sulawesi's geothermal potential area has impermeable hoods with a high level of clay minerals (illite) in alteration regions around geothermal manifestations. Breccia rock samples were taken from one of the wells that had been analyzed to see the effect of temperature on $3 \mathrm{D}$ rock structure changes. Rock samples were given heat induction treatment with varying temperatures ranging from $24^{\circ} \mathrm{C}$ (room temperature), $100^{\circ} \mathrm{C}, 150^{\circ} \mathrm{C}, 200^{\circ} \mathrm{C}$, to $250^{\circ} \mathrm{C}$. Samples at room temperature that have been given treatment are scanned with a Micro- Computed Tomography Scan ( $\mu$-CT Scan) instrument. 300 images of the $\mu$-CT Scan results were reconstructed and characterized by $3 \mathrm{D}$ changes in the fractures using digital image processing. The results are obtained in the form of the main parameters, namely aperture $\{\mathrm{e}(\mathrm{T})\}$, density $\{\Phi(\mathrm{T})\}$, and intensity $\{\mathrm{I}$ (T) $\}$ which tends to increase polynomially.
\end{abstract}

Keywords: Fracture, 3D Rock Structure, Digital Image Processing

\section{Introduction}

Kadidia geothermal area, Sigi, Central Sulawesi province, is one of the non-volcanic geothermal fields are potentially quite good [1]. Kadidia geothermal systems currently on the geological structure Central Sulawesi, which is dominated by plutonic rocks with granite types. The establishment of a geothermal system in the Kadidia area is closely related to the tectonic activity that is still active today, the Palu Koro active fault [2]. Induction of heat can induce fractures formed in rock samples to increase the productivity of geothermal potential [3].

Temperature is a physical parameter that plays an important role in the nature of rocks such as changes in the structure of rocks, minerals or fractures, then cracking, gas changes in underground mining, geothermal energy extraction, and others. This research is a development of previous works aimed at reviewing rock structures using digital image analysis due to heat induction on geothermal potential rocks which results in microstructure changes due to temperature changes [4]. Changes in rock structure in question is a change that occurs in the fracture along with the increase in temperature. 


\section{Method}

The hood rock samples obtained by a rock that comes from drilling wells. Temperature slopes in the Kadidia geothermal prospect area located in Sigi Regency, Kadidia District, Central Sulawesi Province. Rock samples were taken at a depth of $697 \mathrm{~m}$ with a cylindrical shape which has a length of $5 \mathrm{~cm}$ with a diameter of $4.5 \mathrm{~cm}$. Types of rock samples are sedimentary rocks consisting of conglomerates, sandstone, claystone, and breccia. By using micro-CT scans, digital data is obtained to produce three- dimensional images of the stone itself. (see Figure 1).

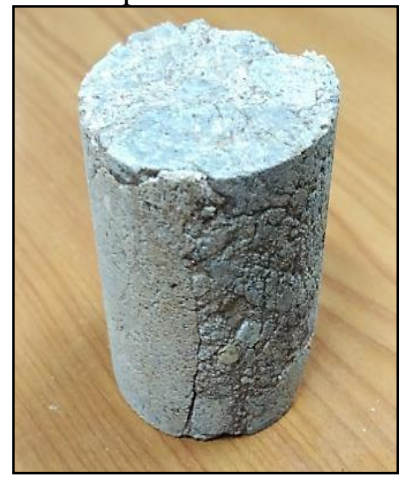

Fig. 1. Geothermal hood rock sample.

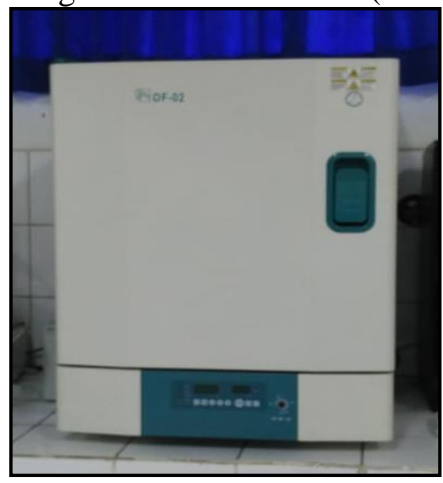

Fig. 2. Oven OF-02G.

The tool used in the process of giving temperature treatment to rocks is Oven OF-02G (seen in Figure 2). Assuming rock samples have an initial temperature at room temperature of $24^{\circ} \mathrm{C}$. The rock sample is then given a temperature treatment with a temperature variation of $100^{\circ} \mathrm{C}$, $150^{\circ} \mathrm{C}, 200^{\circ} \mathrm{C}, 250^{\circ} \mathrm{C}$.

The digital images of the rock were produced by using a SkyScan 1173 micro-CT scan (see Figure 3). This device is specialized to produce high energy of X-ray which is suitable to scan such high-density rock. the scanning parameters are listed in Table 1.

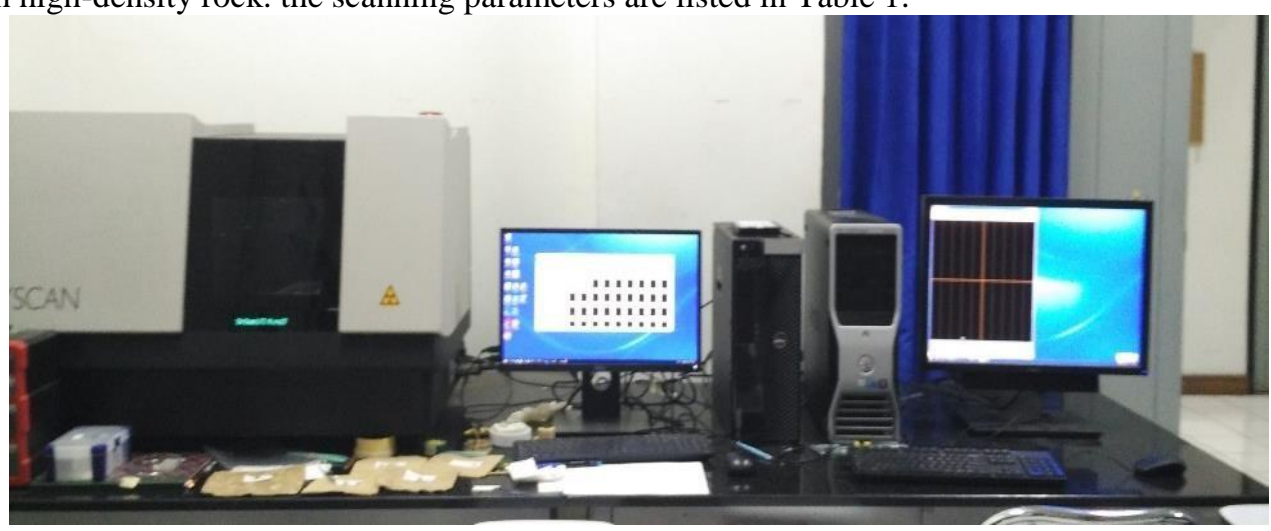

Fig. 3. SkyScan 1173 micro-CT scan device. 
Table 1. Scanning parameter for rock's sample [5].

\begin{tabular}{ll}
\hline Scanner & SkyScan 1173 \\
\hline Sample spatial dimension & $4,5 \mathrm{~cm} \times 4,5 \mathrm{~cm}$ \\
Voltage & $125 \mathrm{kV}$ \\
Rotation step & $0.04^{\circ}$ \\
Filter & $0.25 \mathrm{~mm}$ brass \\
Exposure time & $450 \mathrm{~ms}$ \\
Object-source distance & $182.000 \mathrm{~mm}$ \\
Camera-source distance & $364.000 \mathrm{~mm}$ \\
Image pixel size & 49.875 pixel \\
Scanning interval & 1 hour 49 min 51 sec \\
Number of raw projection images & $1200($ TIFF images $)$ \\
VOI & $300 \times 300 \times 300$ \\
\hline
\end{tabular}

\section{Result and Discussion}

\subsection{Qualitative changes in the fracture}

Two-dimensional visualization of the results of the image reconstruction process and the Region of Interest (ROI) selection process (see Figure 4) with fracture changes in variations in room temperature treatment $24,100,150,200,250$. Changes in fractures in rock samples were viewed qualitatively.

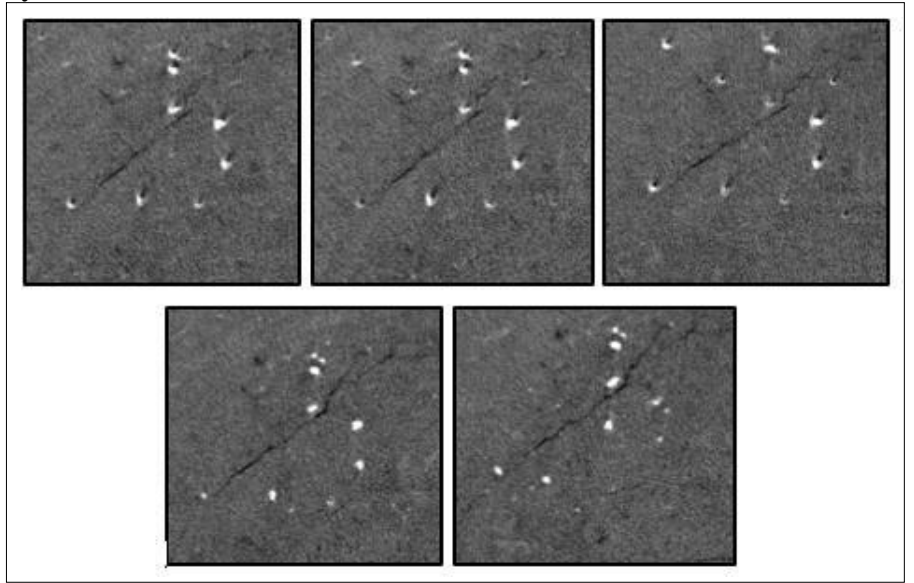

Fig. 4. Qualitative display on the $2 \mathrm{D}$ image of fracture changes at each temperature variant. Top row: at temperature $24^{\circ} \mathrm{C} ; 100^{\circ} \mathrm{C}$; and $150^{\circ} \mathrm{C}$. Bottom row: at temperature $200^{\circ} \mathrm{C}$ and $250^{\circ} \mathrm{C}$.

Qualitatively the fracture visualization in 3D can be seen in Figure 5. The sample rock there is a natural fracture that appears when the condition of the rock is at room temperature, so 
a deeper process is needed to determine whether there is a change due to the influence of temperature.

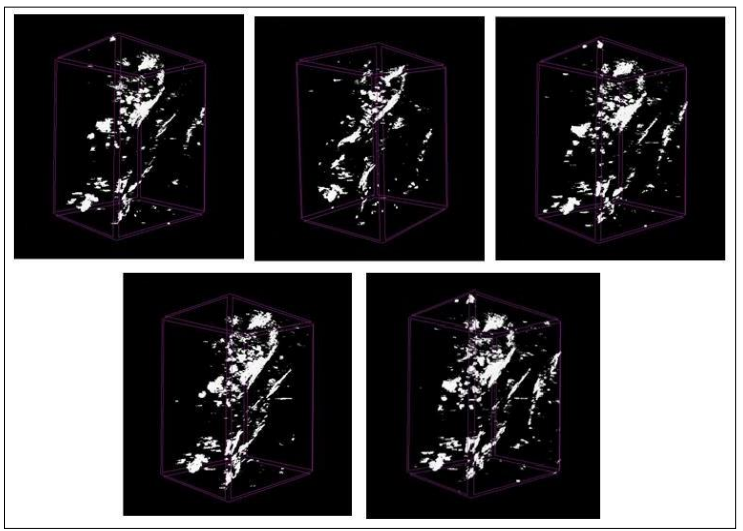

Fig. 5. 3D visual of the digitized sample with white color is a fracture and black color is a matrix. Top row: at temperature $24^{\circ} \mathrm{C} ; 100^{\circ} \mathrm{C}$; and $150^{\circ} \mathrm{C}$. Bottom row: at temperature $200^{\circ} \mathrm{C}$ and $250^{\circ} \mathrm{C}$.

In Figure 5 the fracture changes that occur in 3D visualization due to heat induction with a temperature variation of $24^{\circ} \mathrm{C}, 100^{\circ} \mathrm{C}, 150^{\circ} \mathrm{C}, 200^{\circ} \mathrm{C}, 250^{\circ} \mathrm{C}$. A very significant change occurs when the temperature reaches $200^{\circ} \mathrm{C}$ and $250^{\circ} \mathrm{C}$. This indicates that the temperature treatment can induce the fractures formed in the breccia cap rock samples.

\subsection{Quantitative Changes in The Fracture}

The fracture structure that has changed can also be seen by analyzing quantitatively the main fracture parameters, with parameters consisting of the fracture aperture, fracture density, and fracture intensity. For the results of the fracture aperture changes due to temperature treatment (see Figure 6).

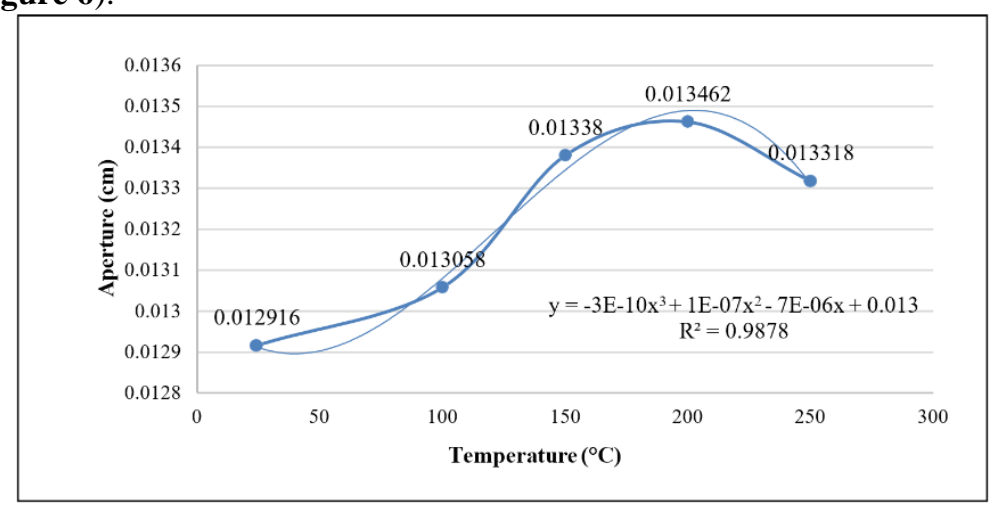

Fig. 6. Effect of temperature on fracture aperture changes.

Mathematically the change in fracture aperture due to the influence of temperature can be written as Equation 1.

$$
e(T)=-3 \times 10^{-1} T^{3}+1 \times 10^{-7} T^{2}-7 \times 10^{-6}+0,013 .
$$


Fractures with increasing temperature will widen, but when the temperature reaches $250^{\circ}$ $\mathrm{C}$ the narrowing occurs again allegedly caused by illite clay minerals that have spread in rock samples. For the results of the fracture density changes due to temperature treatment (see Figure 7).

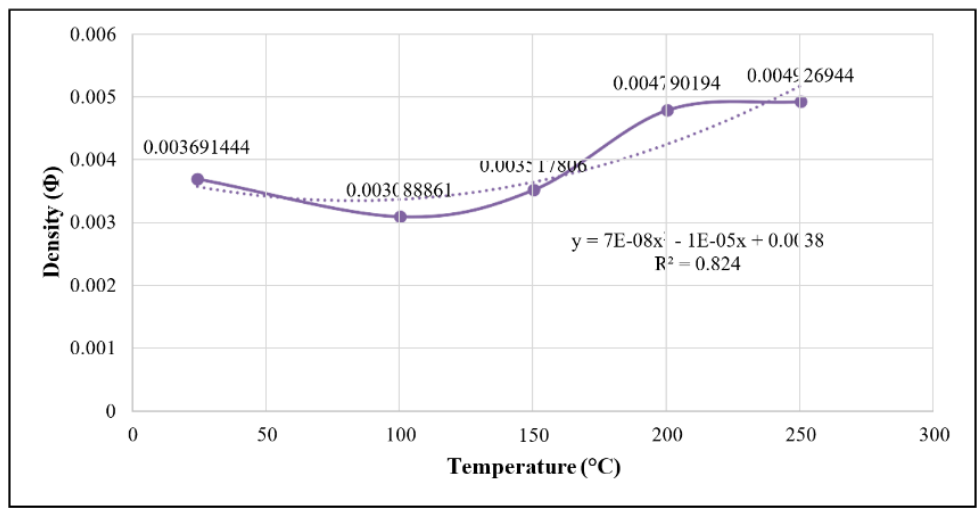

Fig. 7. Effect of temperature on fracture density changes.

Mathematically the change in fracture density due to the influence of temperature can be written as Equation 2.

$$
\Phi(T)=7 \times 10^{-8} T^{2}-0.00001 T+0.0038
$$

The results obtained show the fracture density of temperature changes increases polynomially until the temperature reaches $250^{\circ} \mathrm{C}$, where there is a decrease when the temperature reaches $100^{\circ} \mathrm{C}$, but an increase occurs when the temperature is $150^{\circ} \mathrm{C}$. The most significant increase occurs when the temperature reaches $200^{\circ} \mathrm{C}$.

The changes that occurred allegedly influenced by the $\mathrm{pH}$ of minerals contained in the rocks and cracks, it is based on the change affected breccia rock fracture volume. The rise in temperature can induce new fractures are formed so that the cracks will get bigger volume and also affect the fracture density values contained in rock samples. Therefore, fracture density increases as temperature increase polynomial. For the results of the fracture intensity changes due to temperature treatment (see Figure 8). 


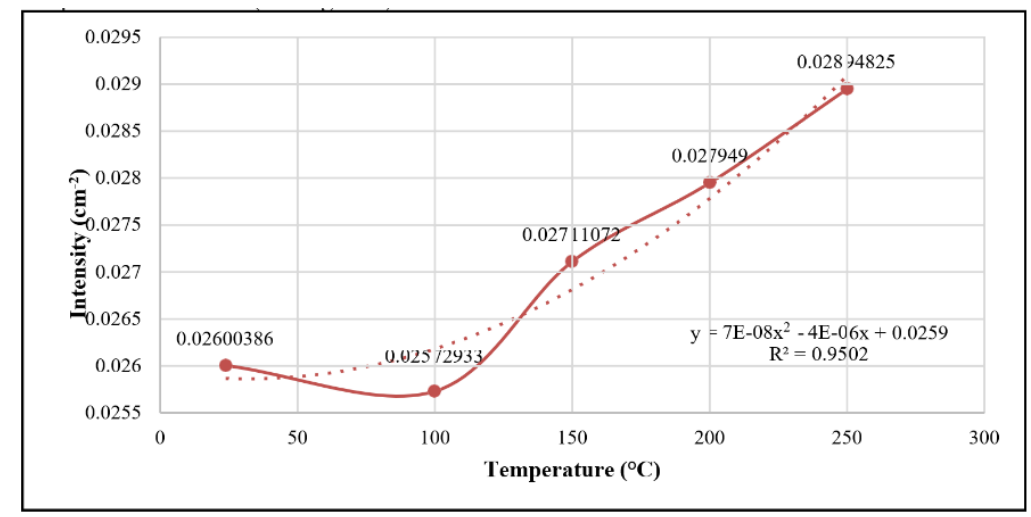

Fig. 8. Effect of temperature on fracture intensity changes.

Mathematically the change in fracture intensity due to the influence of temperature can be written as Equation 3.

$$
I(T)=7 \times 10^{-8} T^{2}-0.000006 T+0.0259 .
$$

Based on Figure 8, fracture intensity increases with polynomial temperature rise. The applied temperature can induce the fracture intensity that exists in altered breccia rocks.

\section{Conclusion}

The physical properties of rocks that change is reviewed in the fracture structure which increases due to the influence of temperature, it was concluded that the fracture structure of Kadidia geothermal rocks experienced a polynomial increase due to heat induction.

Acknowledgments. IA receives partially funded by research program "DPUPT Kemenristekdikti" grant number 074/UN40.D/PP/2018. We also thank Pusat Sumber Daya Mineral, Batubara, dan Panas Bumi who has provided rock samples to complete this research.

\section{References}

[1] Dudi, H., Santia, A. M.: Survei Landaian Suhu Sumur KDD-1 Daerah Panas Bumi Kadidia, Kabupaten Sigi, Provinsi Sulawesi Tengah. Bandung: Pusat Sumber Daya Geologi (2015)

[2] Tim Survei Terpadu: Laporan Akhir Survei Terpadu Geologi, Geokimia, dan Geofisika Daerah Panas Bumi Kadidia, Kabupaten Sigi, Provinsi Sulawesi Tengah (2012)

[3] Charlez, P., Lemonnier, P., Ruffet, C., Boutéca, M. J., \& Tan, C.: Thermally induced fracturing: analysis of a field case in North Sea. In European Petroleum Conference. Society of Petroleum Engineers (1996)

[4] Tobing, P.F.L.: Studi Reekahan Alami 2D Beserta Pemodelannya dan Perubahan Rekahan 3D Akibat Pengaruh Suhu Tinggi Pada Batuan Reservoir Panas Bumi. Skripsi Universitas Pendidikan Indonesia, Bandung (2016) 
[5] Feranie, S., Sasmita, D., \& Latief, F. D. E.: Investigation of 3D fractal dimension sensitivity on 3D fracture parameter. In Journal of Physics: Conference Series (Vol. 1280, No. 2, p. 022056). IOP Publishing (2019) 